\title{
Effect of Graphene with Antioxidant Activity on Matrix Metalloproteinase in HT1080 Cells
}

\author{
Su-Gyeng Lee, Moon-Moo Kim and Yunghee Oh* \\ Department of Chemistry, Dong-Eui University, Busan 614714, Korea
}

Received August 30, 2013 /Revised September 26, 2013 /Accepted October 24, 2013

\begin{abstract}
Graphene is an allotrope of carbon that is composed of one-atom-thick planar sheets. It is known to have a preventive effect on cancer in photothermal therapy and a protective effect in DNA oxidation. The effect of graphene on oxidative stress and matrix metalloproteinases (MMPs) was investigated in human fibrosarcoma HT1080 cells. The results showed that graphene specifically exerted an inhibitory effect on DNA oxidation, but it did not inhibit other oxidative stress. In addition, graphene decreased the expression and the activation of MMP-2 and MMP-9 stimulated by phenazine methosulfate-m, which induces the production of intracellular hydrogen peroxide. In particular, the expression of antioxidant enzymes, such as superoxide dismutase (SOD-2), was decreased in the HT1080 cells, indicating that the decrease in the expression level of SOD was due to the antioxidant effect of graphene. These results suggest that the inhibitory effect of oxidative stress in the presence of graphene could inhibit the expression of MMPs in HT1080 cells. Based on the above results, graphene may have chemoprevention properties through inhibition of MMP-2 and MMP-9 related to metastasis.
\end{abstract}

Key words : Graphene, matrix metalloproteinases (MMPs), HT1080, superoxide dismutase (SOD), antioxidant

\section{서 론}

우리 몸에서는 대사과정 중에 끊임없이 일어나는 산화과정 에 의하여 free radical이 생성이 된다고 보고되고 있다[14]. 이러한 free radical 중에서 활성산소종(reactive oxygen species, ROS)으로 superoxide, hydroxyl radical, singlet oxygen, hydrogen peroxide 등이 있다. 활성산소종은 단백질 효소의 불활성화, 지질과산화, DNA변성 등을 일으켜 세포의 정상적 인 대사과정에 오류를 유발하고, 암이나 심장질환, 뇌혈관질 환, 동맥경화, 고혈압, 당뇨병, 파킨슨질병 등 수많은 질병을 일으키는 것으로 보고되었다[26]. 이러한 질환들을 유발시키 는 활성산소의 발생을 억제하기 위하여 우리 몸에는항산화 시스템이 작용하고 있다. 체내에 존재하는 항산화효소는 superoxide를 산소로 전환시키는 superoxide dismutase (SOD), hydrogen peroxidase 및 catalase를 포함한다[4]. 활성산소는 나이가 들어갈수록 생성량이 증가하여 효소의 활성을 상실 시킬 뿐만 아니라 DNA, RNA 및 세포막을 손상시키고 결국 세포사를 일으키고 조직 손상을 증가 시켜 암과 같은 노화관

\footnotetext{
*Corresponding author

Tel : +82-51-890-1517, Fax : +82-51-890-2620

E-mail : yhoh@deu.ac.kr

This is an Open-Access article distributed under the terms of the Creative Commons Attribution Non-Commercial License (http://creativecommons.org/licenses/by-nc/3.0) which permits unrestricted non-commercial use, distribution, and reproduction in any medium, provided the original work is properly cited.
}

련질환을 유발시킨다고 보고되었다[1, 28].

종양에서는 암세포가 주변 조직으로 침윤 및 전이되기 위해 서는 암세포간 결합력을 약화시켜 서로 분리해야 한다. 서로 분리된 종양세포들은 세포외 기질에 부착하여 기질을 분해하 면서 주변조직으로 침습한다. 이 과정에서 종양세포는 자체적 으로 단백질 분해효소를 분비하거나 섬유아세포 같은 숙주세 포에서 단백질 분해 효소를 분비하도록 유도한다[5]. 여기서 matrix metalloproteinases (MMPs)라고 불리는 기질금속단백 질분해효소가 중요한 역할을 한다[17]. MMPs는 현재 약 20여 종류가 밝혀져 있으며 활성화된 MMPs는 tissue inhibitors of matrix metalloproteinases (TIMPs)라고 불리는 단백질 억제 제와 복합체를 형성하여 활성을 조절한다[30]. 그 중 MMP-2 와 MMP-9은 기저막 분해에 핵심적인 역할을 하는 것으로 알 려져 있어[29], 암세포의 침윤을 매개하는 세포외 기질의 분해 를 억제하기 위하여 MMPs는 필수적으로 억제되어야 한다[6]. 최근 이러한 $\mathrm{MMPs}$ 억제에 관한 연구는 천연물과 유기합성물 질 분야 등에서는 활발히 이루어지고 있으나 나노화합물에 대한 연구는 미비한 실정이다. 그러므로 본 연구는 나노화합 물 중에서도 graphene에 대해 진행 되었다. 이러한 graphene 은 원자 하나의 두께를 가지는 흑연(graphite)의 단층으로써 탄소구조체들 중 하나이다[22]. 최초 K.S. Novoselov와 A.K Geim 등의 스카치테이프를 이용한 발견으로 시작하여 최근에 는 graphene을 손쉽게 얻을 수 있게 되었다[23]. Graphene은 탄소원자의 강한 공유결합으로 형성된 단층으로 이루어진 이 차원 평면구조로 높은 전하이동도와 전류밀도특성, 뛰어난 열 
전도도 및 내화학성을 가지고 있고 유연성과 신축성 또한 가 지고 있다. 다양한 화학적 기능화가 가능하여 최근 실리콘을 기반으로 하는 반도체 산업에서 대체물질로 각광받고 있어 최근 몇 년간 그래핀에 대한 연구가 활발히 진행되고 있다[24, 34]. Biomedical 분야에서도 최근 많은 관심을 끌고 있다[7]. 현재 graphene은 세포 내의 ROS의 증가와 미토콘드리아성 신경경로 활성화에 의해 apoptosis를 유발 한다고 밝혀진 바 있으며[16], 또한 $\mathrm{T}$ 세포 증식 촉진으로 에이즈 바이러스인 HIV-1 치료에 유망한 DNA 백신으로 사용 가능성이 보고 되 고 있다[31]. 그러나 graphene이 암전이와 관련있는 matrix metalloproteinases (MMPs) 억제에 미치는 영향에 관한 연구 보고는 현재까지 미비한 실정이다. 따라서, 본 연구에서는 graphene의 항산화 효능과 더불어 사람 섬유아육종세포를이 용하여 세포독성과 암전이와 관련 있는 $\mathrm{MMPs}$ 억제 효능에 대한 연구가 수행되었다.

\section{재료 및 방법}

\section{Graphene 제조법}

실험에서 사용된 graphene은 graphene carboxylic acid를 이용하여 제조하였다. Graphene carboxylic acid $(0.5 \mathrm{~g})$, water $(20 \mathrm{ml})$ 와 $\mathrm{NaOH}(1 \mathrm{M}$ aqueous solution, $1 \mathrm{ml})$ 의 재료를 Cole-Parmer sonicator를 이용하여 $200 \mathrm{~W}$ 의 출력으로 30 분간 sonicate 시켜 graphene을 제조하였다[10].

\section{재료 및 세포배양}

세포배양을 위한 Dulbecco's Modified Eagle's Medium (DMEM), Trypsin-EDTA, penicillin/streptomycin/ampho-

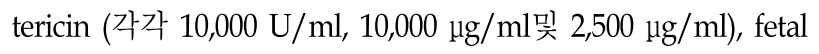
bovine serum (FBS) 시약은 Gibco BRL, Life Technologies (USA)로부터 구입하였다. HT1080 세포는 American Type of Culture Collection (Manassas, VA, USA)로부터 구입하였다. MTT 시약, gelatin, agarose, PMA (phorbol 12-myristate 13-acetate) 및 기타시약은 Sigma Chemical Co. (St. Louis, $\mathrm{MO}, \mathrm{USA}$ )로부터 구입하였다. $\mathrm{HT} 1080$ 세포는 $5 \% \mathrm{CO}_{2}$ 및 $37^{\circ} \mathrm{C}$ 에서 $95 \%$ 이상의 습도를 유지한 배양기에서 $10 \%$ fetal bovine serum, $2 \mathrm{mM}$ glutamine and $100 \mu \mathrm{g} / \mathrm{ml}$ penicillin-streptomy$\operatorname{cin}$ 을 포함하는 DMEM 배지에서 배양하였다.

\section{MTT assay}

Hansen [12] 방법에 따라 HT1080 세포에 대한 graphene의 세포독성을 MTT (3-(4,5-dimethyl-2-yl)-2,5-diphenyltetrazolium bromide)를 이용하여 측정하였다.

\section{항산화 활성 assay}

$\mathrm{DPPH}$ radical assay는 Brand-Williams [13]의 실험방법을
변형하여 1,1-diphenyl-2-picryl- hydrazyl (DPPH) radical에 대한 graphene의 소거능력을 측정하였다[4]. 시험농도의 graphene을 DPPH 용액에 가하여 $10 \mathrm{sec}$ 동안 잘 혼합한 다음 실온에서 $20 \mathrm{~min}$ 동안 반응시킨 후 $525 \mathrm{~nm}$ 에서 흡광도를 측정 하였다. DPPH radical 함량은 시료첨가군과 대조군의 흡광도 비를 \% 값으로 환산하여 나타내었다.

환원력 assay는 Oyaizu의 방법에 따라 측정하였다[25]. 시 료 $1 \mathrm{ml}$ 에 pH 6.6의 $200 \mathrm{mM}$ 인산 완충액 및 $1 \%$ 의 potassium ferricyanide를 각 $1 \mathrm{ml}$ 씩 차례로 가하여 교반한 후 $50^{\circ} \mathrm{C}$ 의 수옥상에서 $20 \mathrm{~min}$ 동안 반응시켰다. 여기에 $10 \% \mathrm{TCA}$ (trichloroacetic acid) 용액을 $1 \mathrm{ml}$ 가하여 $13,500 \times g$ 에서 15 $\min$ 동안 원심분리 하여 상등액 $1 \mathrm{ml}$ 에 증류수 및 ferric chloride 각 $1 \mathrm{ml}$ 을 혼합한 후 $700 \mathrm{~nm}$ 에서 흡광도를 측정하였다. 시료의 환원력은 시료첨가군과 대조군의 흡광도 비를 \% 값으 로 환산하였다.

Superoxide anion 라디칼소거능은 Fidovich [9]의 방법 에 의해 정하였다. 각 시료 용액 $0.1 \mathrm{ml}$ 과 $0.1 \mathrm{M}$ potassium phosphate buffer (pH7.5) $0.6 \mathrm{ml}$ 에 $0.4 \mathrm{mM}$ xanthine과 $0.24 \mathrm{mM}$ nitro blue tetrazolium (NBT)를 녹인 기질액 $1 \mathrm{ml}$ 를 첨가하고 xanthine oxidase $(0.049 \mathrm{U} / \mathrm{ml}) 1 \mathrm{ml}$ 를 가하여 $37^{\circ} \mathrm{C}$ 에서 20 분 간 반응시킨 후 $1 \mathrm{~N}-\mathrm{HCl} 1 \mathrm{ml}$ 를 가하여 반응을 종료시킨 다음, 반응액 중에 생성된 superoxide anion radical의 양을 $560 \mathrm{~nm}$ 에서 흡광도를 측정하였다.

In vitro 지질과산화에 대한 항산화활성응 측정하기 위하여 graphene를 1, 2, 4, 8, 16 및 $32 \mathrm{\mu g} / \mathrm{ml}$ 의 농도로 linolenic acid emulsion과 혼합한 후에 $0.8 \mathrm{mM} \mathrm{H}_{2} \mathrm{O}_{2}$ 및 $0.8 \mathrm{mM} \mathrm{FeSO}_{4}$ 를 혼합한 용액을 $5 \mathrm{hr}$ 동안 반응 후 $0.4 \% \mathrm{TBA}$ 를 첨가하고 $95^{\circ} \mathrm{C}$ 에서 $2 \mathrm{hr}$ 반응시킨 다음 실온에서 $10 \mathrm{~min}$ 동안 반응시켰다. 그 다음 $15: 1$ 비율의 n-butanol : pyridine 용액을 $500 \mu \mathrm{l}$ 첨가하 고 $1,000 \times g$ 에서 $10 \mathrm{~min}$ 동안 원심분리한 후 상등액을 532 $\mathrm{nm}$ 에서 흡광도를 측정하여 지질과산화정도는 시료 첨가 전 후의 흡광도비를 \%값으로 환산하여 나타내었다. 양성대조군 으로는 $0.1 \%$ vitamin $\mathrm{E}$ 를 사용하였다.

Hydroxyl radical에 의한 DNA 손상을 전기영동법으로 분 석을 위하여 Genomic DNA는 약간 변형된 표준 과정에 따라 HT1080 세포로부터 추출하였다[20]. Fenton반응에 의하여 발 생된 hydroxyl radical에 노출된 DNA 산화는 기존에 실험된 방법에 따라 수행되었다[21]. 먼저 $100 \mu \mathrm{ll}$ 의 DNA 용액에 시험 농도의 graphene, $200 \mu \mathrm{M} \mathrm{FeSO}{ }_{4}, 1 \mathrm{mM} \mathrm{H}_{2} \mathrm{O}_{2}$ 및 $50 \mu \mathrm{g} / \mathrm{ml}$ genomic DNA를 첨가하였다. 반응 혼합물을 $30 \mathrm{~min}$ 동안 상 온에서 반응시킨 후 $10 \mathrm{mM}$ EDTA를 첨가하여 반응을 종결시 킨다. $1 \mu \mathrm{g}$ 의 DNA를 포함하는 $20 \mu \mathrm{l}$ 의 반응혼합물을 $1 \%$ agarose gel에서 $100 \mathrm{~V}$ 로 $30 \mathrm{~min}$ 동안 전기영동 하였다. Gel은 $1 \mathrm{mg} / \mathrm{ml}$ ethidium bromide로 염색하여 물로 세척하여 UV로 LAS3000® image analyzer (Fujifilm Life Science, Tokyo, Japan)를 이용하여 관찰하였다. 


\section{Gelatin zymography}

MMP-2 및 MMP-9 활성은 FBS를 첨가하지 않은 DMEM배 지에서 배양한 HT1080 세포에 graphene을 처리한 후 실험을 수행하였다. $50 \mu \mathrm{g}$ 의 총단백질을 함유하는 세포배양액을 1.5 $\mathrm{mg} / \mathrm{ml}$ gelatin을 포함하는 비환원조건의 $10 \%$ polyacrylamide gels를 이용하여 전기영동하였다. Gelatin이 분해된 bands는 청색배경에 투명한 band로 나타난다. Band의 진하기는 $\mathrm{MMPs}$ 의 활성에 비례하여 나타나는데 이는, LAS3000®image analyzer (Fujifilm Life Science, Tokyo, Japan)를 관찰하였다.

\section{Western blot analysis}

$\mathrm{HT} 1080$ 세포에 용출 완충용액 $(50 \mathrm{mM}$ Tris - HCl, pH 7.5, $0.4 \%$ Nonidet P-40, $120 \mathrm{mM} \mathrm{NaCl}, 1.5 \mathrm{mM} \mathrm{MgCl}, 2 \mathrm{mM}$ phenylmethylsulfonyl fluoride, $80 \mathrm{\mu g} / \mathrm{ml}$ leupeptin, $3 \mathrm{mM}$ $\mathrm{NaF}$ and $1 \mathrm{mM} \mathrm{DTT}$ )을 첨가하여 $4^{\circ} \mathrm{C}$ 에서 $30 \mathrm{~min}$ 동안 처리하 였다. $10 \mu \mathrm{g}$ 의 세포용출액을 $10 \% \mathrm{Tris}-\mathrm{HCl}$ gel에서 전기영동 후 단백질을 전기적으로 nitrocellulose membrane으로 전이 시켰다. 그 다음 $10 \%$ skim milk를 nitrocellulose membrane에 전 처리하고 목적 단백질에 대한 1 차 항체를 처리한 다음 2 차 항체를 처리 후, chemiluminescent ECL kit (Amersham Pharmacia Biotech)를 사용하여 목적단백질을 검출하였다. Western blot의 band는 LAS3000® image analyzer (Fujifilm Life Science, Tokyo, Japan)를 이용하여 관찰하였다.

\section{통계처리}

각 실험은 3회 이상 반복실험을 통하여 그 결과를 얻어 각각 의 시료농도에 대해 평균 \pm 표준편차로 나타내었다. 각 시료농 도군에 대한 유의차 검정은 대조군과 비교하여 Student's $t$ test 한 후 $p<0.05$ 값을 통계적으로 유의성 있는 결과로 간주하 였다.

\section{결 과}

\section{세포성장에 대한 graphene의 효과}

Graphene이 세포 독성에 미치는 농도를 조사하기 위하여 MTT assay를 수행하였다. HT1080 세포에 대한 graphene의 세포 독성을 측정한 결과, Fig. 1에서 보는 바와 같이 graphene $32 \mu \mathrm{g} / \mathrm{ml}$ 이하의 농도에서는 대조군과 비교하였을 때 어떠한 독성효과도 없는 것으로 나타났다.

Graphene의 DPPH radical, lipid peroxidation, superoxide anion 소거능 및 환원력

생체 내 산화적 스트레스와 관련되어 있는 DPPH radical, lipid peroxidation, superoxide anion의 소거능 및 환원력에 대하여 조사하였다. DPPH radical 소거법은 항산화 물질에 의한 DPPH radical의 흡광도 변화를 지표로 하여 산화억제

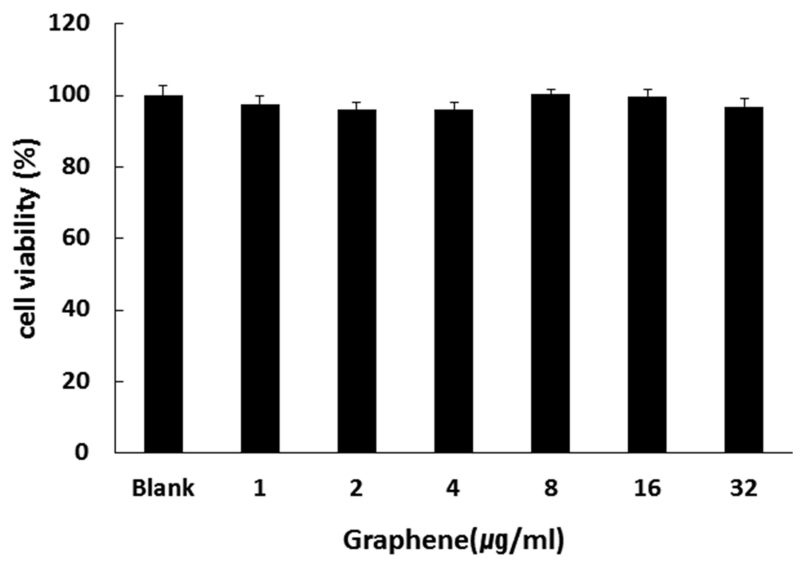

Fig. 1. Effect of graphene on viability of HT1080 cells. HT1080 cells were treated with graphene at 1, 2, 4, 8, 16 and $32 \mu \mathrm{g} / \mathrm{ml}$ and cell viability was determined using MTT assay after $24 \mathrm{~h}$. Data are given as means of values \pm S.D. from three independent experiments. Level of significance was identified statistically using Student's $t$ test.

정도를 예측할 수 있다. Fig. 2A에서 보는 바와 같이 graphene 의 DPPH radical 소거능은 나타나지 않았지만, 양성 대조군인 vitamin C는 $1 \mathrm{\mu g} / \mathrm{ml}$ 이상의 농도에서 $\mathrm{DPPH}$ 에 대한 소거효 과가 나타났다. Fig. 2B에서는 linolenic acid를 Fenton 반응으 로 발생시킨 hydroxyl radical에 노출시켰다. 먼저 hydroxyl radical에 의한 지질 과산화 확인을 위하여 기존에 알려진 친 유성 항산화제인 $1,000 \mu \mathrm{g} / \mathrm{ml}$ 의 vitamin E의 지질과산화에 대한 억제효능을 평가하였으나 vitamin $\mathrm{E}$ 는 효과를 보였으나 graphene은 효과가 없는 것으로 나타났다. Superoxide anion 소거능을 측정하는 실험인 Fig. 2 C에서는 양성 대조군인 $\mathrm{SOD}$ 에서는 뛰어난 효과가 나타났으며, 또한 graphene에서도 superoxide anion 소거능에 효과가 있는 것으로 나타났다. Fig. 2D에서 보는 바와 같이 양성 대조군인 vitamin $\mathrm{C}$ 의 농도에 따라 환원력이 증가하는 것으로 나타났으나 graphene의 환원 력은 $32 \mu \mathrm{g} / \mathrm{ml}$ 이하의 농도에서 관찰되지 않았다.

Hydroxyl radical에 의한 genomic DNA 산화에대한 graphene의 보호효과

사람 섬유아육종세포인 HT1080 세포로부터 분리한 genomic DNA를 이용하여 Fenton 반응에 의하여 발생된 hydroxyl radical에 의한 DNA의 산화적 손상에 대한 graphene 의 보호효과를 조사하였다. 대조군의 genomic DNA는 Fig. 3 에서와 같이 분해되는 것을 확인할 수 있었다. 그러나 graphene을 첨가한 군에서는 $1 \mu \mathrm{g} / \mathrm{ml}$ 이상 농도의 graphene에 서 genomic DNA의 산화적 손상이 유의성 있게 억제되었다. Hydroxyl radical에 의한 DNA의 산화적 손상은 농도에 비례 하여 억제되는 것으로 나타났다. 
A

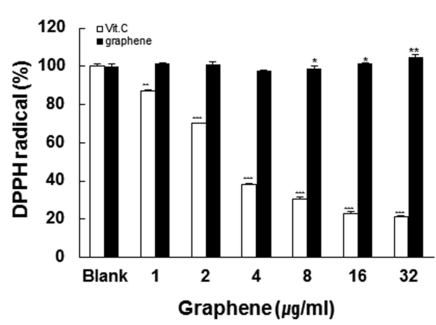

C

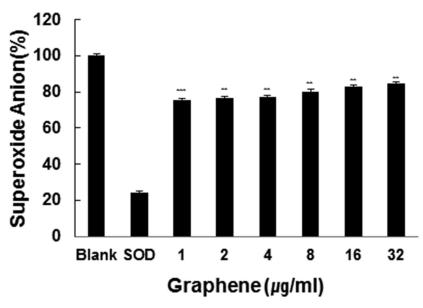

B


Fig. 2. The antioxidant activities of graphene in vitroThe effect of graphene on scavenging of DPPH (A) and inhibition of lipid peroxidation in vitro (B) were investigated. Vitamin E at $1,000 \mu \mathrm{g} /$ mlwastestedas a positive control. Scavenging activity of graphene on superoxide anion $(\mathrm{C})$ and its reducing power (D) were estimated. Vitamin $\mathrm{C}$ was used as a positive control in this experiment. Data are given as means of values \pm S.D. from three independent experiments compared with control $\left({ }^{*} p<0.05,{ }^{* *} p<0.01\right)$.
PMS와 PMA로 자극된 HT1080 세포에서 MMP-2 and MMP-9 활성에 대한 graphene의 효과

Graphene이 MMP-2 및 MMP-9의 활성에 미치는 영향을 조사하기 위하여 암전이에 널리 이용되는 사람 섬유아 육종세 포인 $\mathrm{HT} 1080$ 세포를 이용하였다. 먼저 MMPs의 분비를 자극 시키기 위하여 세포 내에서 $\mathrm{H}_{2} \mathrm{O}_{2}$ 을 생성시키는 phenazinemethosulfate (PMS)와 protein kinase $\mathrm{C}$ 의 강력한 activator인 phorbol-12-myristate-13-acetate (PMA)로 자극하였다. 그 다

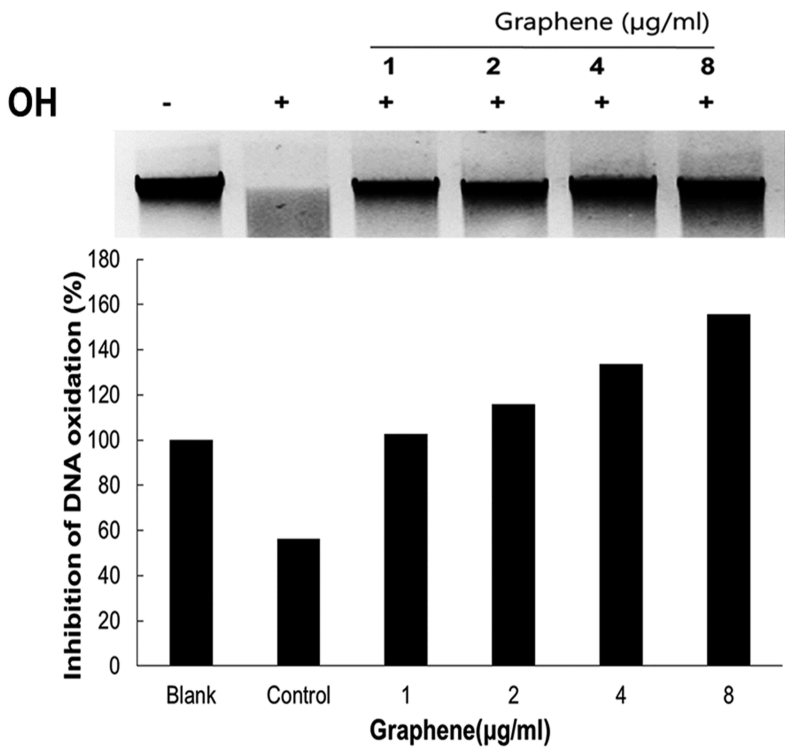

Fig. 3. Protective effect of graphene on DNA oxidative damage induced by hydroxyl radical. Genomic DNA purified from HT1080 cells was pre-treated with graphene for 1 $\mathrm{h}$ exposed to $\cdot \mathrm{OH}$ using Fenton reaction. After $30 \mathrm{~min}$, reaction mixture containing about $1 \mu \mathrm{g}$ of DNA was electrophorased on a $1 \%$ agarose gel for $30 \mathrm{~min}$ at $100 \mathrm{~V}$ and visualized by UV light after stained with $1 \mathrm{mg} / \mathrm{ml}$ ethidium bromide.
음 $72 \mathrm{hr}$ 동안 세포를 배양 후 세포배양 상등액을 이용하여 gelatin zymograhpy를 수행하였다. Fig. 4에서 보는 바와 같이 PMS 및 PMA로 자극한 대조군은 자극제를 처리하지 않은 공 시험군에 비하여 전체적으로 MMP-2 및 MMP-9 효소활성이 증가하는 것으로 나타났다. 특히, PMA처리군에서는 공시험 군에 비하여 MMP-9의 효소활성이 현저하게 증가하였다. Fig. $4 \mathrm{~A}$ 에서 보여지는 바와 같이 graphene의 PMS처리군에서는 $16 \mathrm{\mu g} / \mathrm{ml}$ 이상의 농도에서 MMP-2와 MMP-9의 활성이 모두
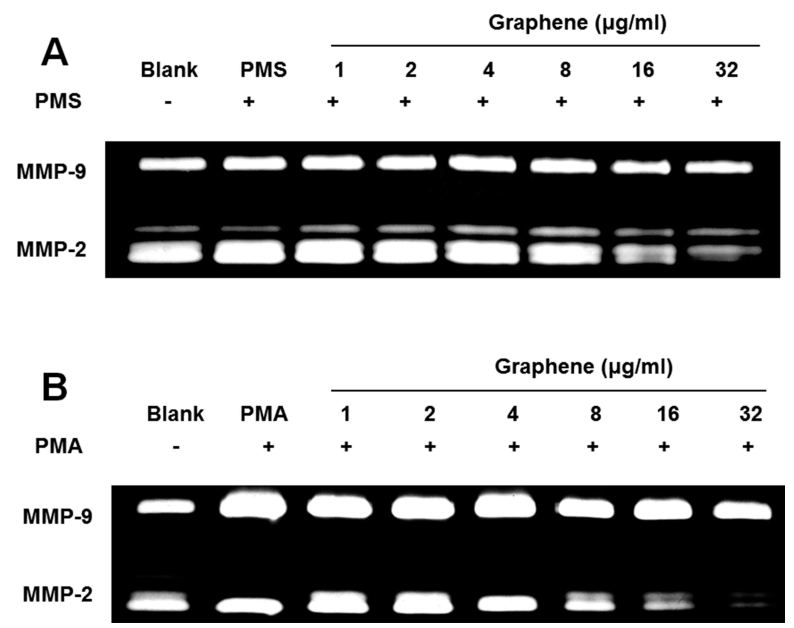

Fig. 4. Effect of graphene on activities of MMP-2 and -9 in HT1080 cells. The cells stimulated with $1 \mu \mathrm{g} / \mathrm{ml}$ of PMS (A) and $32 \mu \mathrm{g} / \mathrm{ml}$ of PMA (B) to induce MMPs expression were treated with graphene at 1, 2, 4, 8, 16, $32 \mathrm{\mu g} / \mathrm{ml}$ under serum-free conditions for $72 \mathrm{~h}$. MMP-2 and -9 activities in conditioned media were determined by gelatin zymography. Values are expressed as relative MMPs activities using the following equation. Relative MMPs activity $(\%)=$ (intensity of a band/total intensity of blank band $\times 100$. Data are given as means of values \pm S.D. from three independent experiments. 


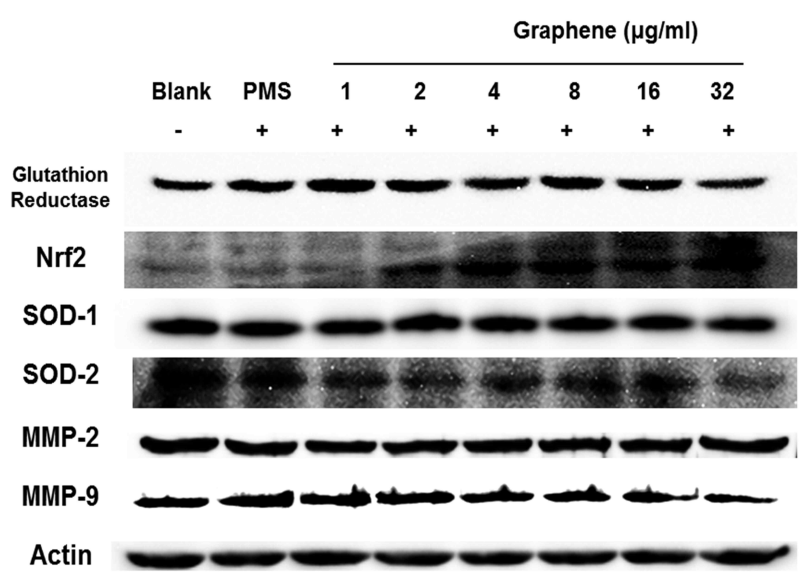

Fig. 5. Effect of graphene on protein expressions of MMP-2, -9 , SOD-1, -2, Nrf2 and glutationreductase in HT1080 cells.HT1080 cells were treated with graphene at 1, 2, 4, 8, 16, $32 \mu \mathrm{M}$ Western blot analyses of cell lysates were performed using antibodies as indicated.

감소되고, Fig. $4 \mathrm{~B}$ 에서 보여지는 바와 같이 $\mathrm{PMA}$ 처리군에서는 $8 \mathrm{\mu g} / \mathrm{ml}$ 이상의 농도에서 MMP-2와 MMP-9의 활성이 모두 감소되는 것을 확인할 수 있었다.

PMS로 자극된 HT1080에서 MMP-2 및 MMP-9의 단백 질 발현 억제 효과

Graphene의 MMP-2 및 MMP-9의 활성에 대한 억제 효과가 단백질 발현의 수준에서 조절되는지를 연구하기 위하여 Western blot을 시행하였다. Fig. 5에서 보여지는 바와 같이 MMP-2의 단백질 발현은 억제되지 않으나 MMP-9의 단백질 발현이 16 $\mu \mathrm{g} / \mathrm{ml}$ 농도 이상의 graphene에 의하여 뚜렷하게 억제되는 것으로 나타나, graphene은 MMP-9의 단백질 발현을 억제시 키는 것으로 판정되었다. 한편 graphene이 항산화 효소의 발 현을 조절하는데 가장 중요한 전사인자인 Nrf2에 의하여 조절 되는 SOD-1, SOD-2 및 glutathione reductase (GR)의 발현에 미치는 영향을 조사하였다. Graphene은 $32 \mathrm{\mu g} / \mathrm{ml}$ 이하의 농 도에서 Nrf2의 발현을 증가 시켰으나 SOD-2의 발현은 감소 시켰고 SOD-1와 GR의 단백질 발현 수준에서는 변화가 없는 것으로 나타났다.

\section{고 찰}

생물의 호흡을 통해 얻어진 산소는 에너지를 만드는 과정에 사용되는데, 이 과정에서 불완전한 환원이 일어나 $5 \%$ 이하의 물로 환원되지 않은 산소가 전자 하나를 잃어버려 radical 상 태의 활성산소(reactive oxygen species, ROS)가 된다[11]. $\mathrm{ROS}$ 는 세포 구성 성분들인 지질, 단백질, 탄수화물 및 DNA와 반응하여 산화적 손상 및 효소활성을 변화시켜 뇌졸중 및 파 킨슨씨 병과 같은 뇌 질환뿐만 아니라 심장질환, 동맥경화,
암 등과 같은 각종 질병을 일으키는 원인이 되고 노화를 촉진 시킨다고 보고 되고 있다[15]. 이에 본 연구는 graphene의 항 산화 효과를 알아보기 위해 DPPH radical, lipid peroxidation, Superoxide anion 및 Reducing power, Hydroxyl radical에 의한 genomic DNA 산화에 대한 graphene의 항산화효과 연 구를 수행 하였다. Hydroxyl radical은 생체 내에서 DNA와 반응하여 돌연변이 및 세포독성을 유발하여 세포에 손상을 준다[19]. 본 연구에서 graphene은 DPPH radical 소거능, lipid peroxidation 및 reducing power에서는 효과를 나타내지 않았 으나, superoxide anion의 소거능은 있는 것으로 나타났다. 더 욱이 HT1080 세포로부터 genomic DNA를 분리하여 hydrox$\mathrm{yl}$ radical에 의하여 유발되는 DNA 산화에 대한 보호효과는 graphene의 농도에 비례하여 증가하여 산화적 스트레스로부 터 DNA 보호 효과가 있는 것을 알 수 있었다. 이러한 결과는 HeLa cells에서 cellular delivery 중 graphene이 DNA의 보효 효과를 가진다는 연구 결과와 일치하는 바가 있으며[18], 따라 서 graphene은 과산화수소를 유의성있게 소거함으로써 DNA 의산화를 막아 여러 가지 질병과 암으로부터 보호 효과를 나 타낼 수 있음을 알 수 있었다.

암의 진행과정은 3 단계로 이루어져 있다. 첫 번째 활성산소 같은 각종 스트레스를 받은 DNA가 교란, 손상을 입어 암세포 로 변해가는 과정인 initiation 단계, 두 번째 분열과 증식으로 비정상적으로 증식하는 단계인 promotion 단계 세 번째 침윤, 전이 등의 악성종양 유전자의 발현과정인 progression 단계이 다. 암 전이는 세포의 이동, 부착, 침범 등 복잡한 과정을 통해 이루어진다. 초기 종양으로부터 전이성 암세포가 떨어져 나와 다른 조직으로 들어가 증식하여 2차 종양을 형성 하는 것을 말한다. 이러한 과정 중 필수적인 현상이 바로구조단백질로 구성된세포외기질의분해이다 $[2,3]$. 단백질의 분해에서 가장 중요하게 작용하는 단백질 분해효소는 $\mathrm{MMPs}$ 이며, 약 20 여 종의 MMPs 중에 MMP-2와 MMP-9은 type IV 콜라겐을 분해 하여 각종 종양의 국소 침윤이나 전이과정에 관여 한다고 알 려져 있다[33]. 이러한 암에 관한 graphene의 알려진 결과로는 photothermal therapy를 이용한 암 치료방법이 알려져 있으 나 $\mathrm{MMP}$ 억제를 통한 암 전이 억제에 관한 연구결과는 밝혀진 바가 없다[32]. 본 연구에서는 HT1080세포에서 분비되는 MMP-2 및 MMP-9의 활성에 대한 graphene의 효능을 조사하 기 위하여 gelatin zymography 및 western blot 실험을 수행하 였다. 두 실험 모두 PMS로 자극 시킨 후 MMPs의 활성과 발현 에 대하여 조사되었다. 실험결과 gelatin zymography에서는 MMP-2 및 MMP-9 두 가지 효소활성에 대하여 억제효과가 있는 것으로 나타났다. Western blot 분석에서는 graphene이 암전이와 관련있는 MMP-9의 발현을 감소시켰다. 뿐만 아니 라항산화 효소의 발현을 촉진하는 전사인자인 Nrf2 [27]의 발 현을 증가시켰다. 그러나 본 연구에서 활성산소를 감소시키 는 SOD-1과 SOD-2 [8]의 발현 정도를 알아본 결과에서는 
SOD-2의 발현을 감소시키는 것으로 나타났다. 여기서 graphene의 자체 항산화력이 뛰어나 Nrf2의 발현은 증가하지만 SOD-1, SOD-2의 발현을 증가시키지 않음을 알 수 있다. 이러 한 graphene의 항산화력은 MMP-2, MMP-9의 활성억제에 관 여하여 암전이를 억제시킬 가능성이 있다는 것을 알 수 있다. 이러한 본 연구에서 발견된 효능의 결과로 graphene이 하나의 암전이 작용기전을 억제할 수 있음을 알게 되었다. 이러한 연 구 결과를 바탕으로 graphene은 암 전이와 관련 있는 MMP-2 및 MMP-9의 활성과 발현을 억제하여 암 억제에 도움을 줄 수 있는 하나의 우수한 산업화를 위한 생의학 응용소재로 이 용될 수 있으리라 기대된다.

\section{감사의 글}

이 논문은 2013학년도 동의대학교 교내연구비(2013AA077) 에 의해 연구되었음.

\section{References}

1. Bandyopadhyay, U., Das, D. and Banerjee, R. K. 1999. Reactive oxygen species: Oxidative damage and pathogenesis. Curr Sci 77, 658-666.

2. Basset, P., Okada, A., Chenard, M. P., Kannan, R., Stoll, I., Anglard, P., Bellocq, J. P. and Rio, M. C. 1997. Matrix metalloproteinases as stromal effectors of human carcinoma progression: therapeutic implications. Matrix Biol 15, 535-541.

3. Chambers, A. F. and Matrisian, L. M. 1997. Changing views of the role of matrix metalloproteinases in metastasis. $J$ Natl Cancer Inst 89, 1260-1270.

4. Choi, G., Jeong, C., Kim, J., Kwak, J., Shin, Y., Lee, S., Cho, S., Choi, S. and Heo, H. 2009. Effect of storage temperature and water activity on antioxidant activities of powdered green tea extracts. Korean J Food Preserv 16, 333-341.

5. Curran, S. and Murray, G. I. 1999. Matrix metalloproteinases in tumour invasion and metastasis. J Pathol 189, 300-308.

6 Curry, J. D., Glaser, M. C. and Smith, M. T. 2001. Realtime reverse transcription polymerase chain reaction detection and quantification of $\mathrm{t}(1 ; 19)(\mathrm{E} 2 \mathrm{~A}$ - PBX1) fusion genes associated with leukaemia. Br J Haematol 115, 826-830.

7. Feng, L. and Liu, Z. 2011. Graphene in biomedicine: opportunities and challenges. Nanomedicine 6, 317-324.

8. Fridovich, I. 1995. Superoxide radical and superoxide dismutases. Annu Rev Biochem 64, 97-112.

9. Fridovich, I. 1997. Superoxide anion radical, superoxide dismutases, and related matters. J Biol Chem 272, 18515-18517.

10. Gilje, S., Han, S., Wang, M., Wang, K. L. and Kaner, R. B. 2007. A chemical route to graphene for device applications. Nano Lett 7, 3394-3398.

11. Halliwell, B. 1997. Antioxidants and human disease: a general introduction. Nutr Rev 55, S44-S49.

12. Hansen, M. B., Nielsen, S. E. and Berg, K. 1989. Re-examination and further development of a precise and rapid dye method for measuring cell growth/cell kill. J Immunol Methods 119, 203.

13. Imai, J., Ide, N., Nagae, S., Moriguchi, T., Matsuura, H. and Itakura, Y. 1994. Antioxidant and radical scavenging effects of aged garlic extract and its constituents. Planta Med 60, 417.

14. Lee, K. W., Lee, H. J., Surh, Y. J. and Lee, C. Y. 2003. Vitamin $\mathrm{C}$ and cancer chemoprevention: reappraisal. Am J Clin Nutr 78, 1074-1078.

15. Li, H. C., Yashiki, S., Sonoda, J., Lou, H., Ghosh, S. K., Byrnes, J. J., Lema, C., Fujiyoshi, T., Karasuyama, M. and Sonoda, S. 2000. Green tea polyphenols induce apoptosis in vitro in peripheral blood $\mathrm{T}$ lymphocytes of adult T-cell leukemia patients. Jpn J Cancer Res 91, 34-40.

16. Li, Y., Liu, Y., Fu, Y., Wei, T., Le Guyader, L., Gao, G., Liu, R. S., Chang, Y. Z. and Chen, C. 2011. The triggering of apoptosis in macrophages by pristine graphene through the MAPK and TGF-beta signaling pathways. Biomaterials 33, 402-411.

17. Liao, H. F., Chen, Y. Y., Liu, J. J., Hsu, M. L., Shieh, H. J., Liao, H. J., Shieh, C. J., Shiao, M. S. and Chen, Y. J. 2003. Inhibitory effect of caffeic acid phenethyl ester on angiogenesis, tumor invasion, and metastasis. J Agr Food Chem 51, 7907-7912.

18. Lu, C. H., Zhu, C. L., Li, J., Liu, J. J., Chen, X. and Yang, H. H. 2010. Using graphene to protect DNA from cleavage during cellular delivery. Chem Comm 46, 3116-3118.

19. Manian, R., Anusuya, N., Siddhuraju, P. and Manian, S. 2008. The antioxidant activity and free radical scavenging potential of two different solvent extracts of Camellia sinensis (L.) O. Kuntz, Ficus bengalensis L. and Ficus racemosa. Food Chem 107, 1000-1007.

20. Maniatis, T. 1989 Molecular cloning: a laboratory manual/s. Sambrook, EF Fritsch, T. Maniatis. New York: Cold Spring Harbor Laboratory Press.

21. Milne, L., Nicotera, P., Orrenius, S. and Burkitt, M. 1993. Effects of glutathione and chelating agents on copper-mediated DNA oxidation: pro-oxidant and antioxidant properties of glutathione. Arch Biochem Biophys 304, 102-109.

22. Neto, A. H. C., Guinea, F., Peres, N., Novoselov, K. and Geim, A. 2009. The electronic properties of graphene. ReV Mod Phy 81, 109.

23. Novoselov, K., Geim, A., Morozov, S., Jiang, D., Zhang, Y., Dubonos, S., Grigorieva, I. and Firsov, A. 2004. Electric field effect in atomically thin carbon films. Science 306, 666-669.

24. Novoselov, K., Geim, A. K., Morozov, S., Jiang, D., Grigorieva, M. I. K. I. V., Dubonos, S. and Firsov, A. 2005. Two-dimensional gas of massless Dirac fermions in graphene. Nature 438, 197-200.

25. Oyaizu, M. 1986. Studies on products of the browning reaction. Antioxidative activities of browning reaction products prepared from glucosamine. Jpn J Nut 44, 307-315.

26. Rhim, T. and Choi, M. 2010. The antioxidative effects of Ampelopsis brevipedunculata extracts. Korean J Plant Res 23, 445-450.

27. Shen, G., Jeong, W. S., Hu, R. and Kong, A. N. T. 2005. 
Regulation of Nrf2, NF- $\kappa \mathrm{B}$, and AP-1 signaling pathways by chemopreventive agents. Antioxidredox Signal 7, 16481663.

28. Simon, H. U., Haj-Yehia, A. and Levi-Schaffer, F. 2000. Role of reactive oxygen species (ROS) in apoptosis induction. Apoptosis 5, 415-418.

29. Stetler-Stevenson, W. G. 1990. Type IV collagenases in tumor invasion and metastasis. Cancer Metastasis Rev 9, 289303.

30. Vihinen, P. and Kähäri, V. M. 2002. Matrix metalloproteinases in cancer: prognostic markers and therapeutic targets. Int $J$ Cancer 99, 157-166.

31. Xu, L., Liu, Y., Chen, Z., Li, W., Wang, L., Wu, X., Ji, Y. and Zhao, Y. 2012. Surface-engineered gold nanorods: promising DNA vaccine adjuvant for HIV-1 treatment. Nano Lett 12, 2003-2012.

32. Yang, K., Zhang, S., Zhang, G., Sun, X., Lee, S. T. and Liu, Z. 2010. Graphene in mice: ultrahigh in vivo tumor uptake and efficient photothermal therapy. Nano Lett 10, 3318-3323.

33. Zeng, Z. S., Cohen, A. M. and Guillem, J. G. 1999. Loss of basement membrane type IV collagen is associated with increased expression of metalloproteinases 2 and 9 (MMP-2 and MMP-9) during human colorectal tumorigenesis. Carcinogenesis 20, 749-755.

34. Zhang, Y., Tan, Y. W., Stormer, H. L. and Kim, P. 2005. Experimental observation of the quantum Hall effect and Berry's phase in graphene. Nature 438, 201-204.

\section{초록 : 항산화 활성을 가진 그래핀이 HT1080 세포에서 기질금속단백질분해효소에 미치는 영향 \\ 이수경·김문무 · 오영희ᄎ \\ (동의대학교 화학과)}

그래핀(graphene)은 원자 하나의 두께를 가지는 흑연(graphite)의 단층으로서 탄소구조체들 중 하나이다. 그래 핀은 최근 의학분야에서 광열요법을 이용한 암 발생의 예방효과와 DNA의 산화에 대한 보효효과를 가진다고 밝 혀진 바 있다. 본 연구에서는 사람 섬유아육종세포(HT1080)에서 산화 스트레스와 MMPs에 대한 그래핀의 효과가 조사되었다. 항산화 효과에 대한 연구에서 그래핀은 DNA 산화에 대한 억제효과를 특이하게 나타내었으나 다른 산화 스트레스는 억제하지 않았다. 뿐만 아니라 그래핀은 세포 내 과산화수소를 생성시키는 phenazinemethosulfate (PMS)에 의하여 자극된 MMP-2 및 MMP-9의 발현과 활성을 감소시켰다. 특히 superoxide dismutase (SOD-2)와 같은 항산화 효소의 발현이 HT1080세포에서 감소하였는데, 이것이 시사하는 바는 SOD 발현수준의 감소가 그래핀의 항산화 효과로부터 기인 되었다는 것을 나타낸다. 이상의 결과로 그래핀의 존재에서 산화스트레 스의 억제효과가 HT1080 세포에서 MMP-9의 활성과 발현을 감소시킬 수 있다는 것을 암시하고 있다. 이러한 연 구 결과를 바탕으로 그래핀은 암 전이와 관련 있는 MMP-2 및 MMP-9의 활성과 발현의 억제를 통하여 암 억제에 도움을 줄 수 있어, 산업화를 위한 하나의 우수한 생의학 응용소재로 이용될 수 있으리라 기대된다. 